\title{
REVIEW
}

\section{Triple-Negative Breast Cancer, Stem Cells, and African Ancestry}

\author{
Evelyn Jiagge, ${ }^{* \dagger}$ Dhananjay Chitale, ${ }^{\ddagger}$ and Lisa A. Newman ${ }^{\S}$
}

From the Department of Internal Medicine* and Comprehensive Cancer Center, ${ }^{\dagger}$ University of Michigan, Ann Arbor; and the Departments of Pathology ${ }^{\ddagger}$ and Surgery, ${ }^{\S}$ International Center for the Study of Breast Cancer Subtypes, Henry Ford Health System and Henry Ford Cancer Institute, Detroit, Michigan

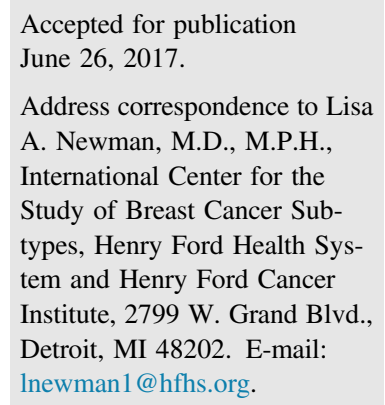

\begin{abstract}
Triple-negative breast cancers (TNBCs) are more common among African-ancestry populations, such as African Americans and western, sub-Saharan Africans, compared with European-ancestry populations. This phenotype prevalence contributes to disparities in breast cancer outcomes between African Americans and White Americans. Breast cancer stem cells represent the tumor subpopulation involved in metastatic virulence, and ongoing research seeks to characterize the extent to which TNBC versus nonTNBC stem cells may differ. This review summarizes the existing literature regarding TNBCs and stem cells as they pertain to the burden of breast cancer among African-ancestry populations. Additional research related to variations in somatic tumor genomics between the African-American and WhiteAmerican populations is also summarized. This review furthermore explores the history of insights regarding breast cancer disparities related to racial/ethnic identity, socioeconomic status, and tumor biology. (Am J Pathol 2018, 188: 271-279; https://doi.org/10.1016/j.ajpath.2017.06.020)
\end{abstract}

Triple-negative breast cancer (TNBC) is the term commonly used to describe cancers that are negative for the expression of estrogen and progesterone receptors and that lack overexpression of tyrosine kinase-type cell surface receptor HER $2 / \mathrm{Neu}$. Approximately $80 \%$ of TNBC tumors have the inherently aggressive basal breast cancer subtype as defined by gene-expression studies; the TNBC phenotype is therefore often used as a surrogate to identify patients with the biologically unfavorable basal subtype. The absence of expression of these three biomarkers also carries clinical relevance with regard to the mechanisms of currently available targeted therapies for breast cancer. An array of selective estrogen receptor modulators and aromatase inhibitors can be offered as endocrine therapy for patients with hormone receptor-positive breast cancer, and targeted antiHER2 agents are effective in managing HER2/Neu-overexpressing breast cancers. Systemic therapy is especially important in addressing the virulent nature of most TNBC cases, but general, nontargeted chemotherapy remains the standard-of-care, routine approach.

Recent data suggest that breast cancers are heterogeneous and that only a small and discrete subpopulation of cells within a tumor, called the breast cancer stem cells (BCSCs), possesses self-renewal capacity and the ability to establish metastatic colonies. ${ }^{1,2}$

Population-based breast cancer mortality rates are higher among women who self-identify as African American compared with White Americans (alias Caucasian Americans). The burden of breast cancer mortality is also elevated among African women residing on the continent of Africa. These two populations will be described as having African ancestry.

TNBCs, BCSCs, and breast cancer patients of African ancestry represent three distinct topics that feature at least one common denominator: an association with increased breast cancer virulence. Each of these topics can be furthermore correlated with one another to varying degrees: i) TNBC is more common among women of western, sub-Saharan African ancestry ${ }^{3-6}$; ii) TNBC/basal subtype tumors are enriched

Supported in part by Susan G. Komen for the Cure Komen Scholars Leadership grant HFHS F11047 (L.A.N.).

Disclosures: None declared.

This article is part of a review series on understanding the complex role of race in cancer health disparities. 
with populations of cells that express BCSC markers ${ }^{7-10}$; and iii) breast cancer patients of western, sub-Saharan African ancestry have an increased prevalence of tumors that express stem cell markers. ${ }^{11-14}$

The extent to which the correlations described above represent evidence of genetic/hereditary variation in BCSCs associated with African ancestry versus representing the true, true and unrelated non sequitur remains uncertain. This review will summarize the published literature on TNBC, BCSCs, and their possible relationships with African ancestry. Our group has introduced the term oncologic anthropology as a transdisciplinary field of study that combines the expertise of social scientists, geneticists, and translational oncologists in an effort to address these complex issues. ${ }^{15}$

\section{Breast Cancer Disparities, TNBC, and African Ancestry}

\section{Background: Epidemiology and Socioeconomic Status}

Disparities in breast cancer outcomes related to racial/ethnic identity have been well documented for several decades, with the most prominent correlation being higher mortality rates among African-American compared with White-American women. ${ }^{16,17}$ Poverty rates and inadequate health insurance coverage are also more common in the African-American compared with White-American communities, and these socioeconomic disadvantages likely contribute to the disparities in breast cancer outcomes by causing delays in diagnosis, more advanced stage distribution at diagnosis, and inadequate multidisciplinary breast cancer treatment. ${ }^{18-20}$ The downstream effects of impaired health care access do not completely explain the disparities in breast cancer outcomes, as African Americans have worse survival rates even after controlling for stage at diagnosis. ${ }^{15,21}$ An evaluation of race/ ethnicity-associated variations in primary tumor biology is therefore warranted, and the presence of such differences is supported by additional epidemiologic data regarding the burden of breast cancer in diverse population subsets.

Historically, population-based incidence rates of breast cancer have been lower in African-American compared with White-American women, and fluctuations in incidence have typically occurred in parallel. Paradoxically, however, population-based breast cancer mortality rates were similar in both groups until the early 1980s, at which point the mortality curves separated as a consequence of declining mortality rates in White Americans contrasted against relatively stable mortality rates in African Americans. The mortality gap that emerged very likely reflected the unmasking of differences in the biology of breast cancer between African-American and White-American women related to the prevalence of biomarker expression and the development of targeted therapy for breast cancer. Tamoxifen became approved as systemic therapy for breast cancer in 1977, and this endocrine agent represents the first targeted therapy for breast cancer, improving outcomes in hormone receptor-positive disease. Tamoxifen-related reductions in population-based mortality rates became apparent by the early 1980s, but these benefits were predominantly experienced by the White-American patient population, because hormone receptor-positive breast cancer is twice as common among White Americans compared with African Americans. ${ }^{22}$

Population-based breast cancer incidence rates have been rising disproportionately among African Americans in recent years, and these rates have now converged with those of White Americans. ${ }^{16}$ Rising incidence of breast cancer coupled with the disproportionately high frequency of the biologically aggressive TNBC phenotype in AfricanAmerican women have resulted in worsening of the breast cancer population-based mortality gap, and this disparity is now a difference of $42 \% .^{16}$

\section{Disparities: Socioeconomic Status versus Tumor Biology}

A variety of epidemiologic and statistical research tools have been utilized in the effort to disentangle the effects of AfricanAmerican identity from the potentially confounding influences of socioeconomic disadvantage on breast cancer risk and outcome. Two sequential meta-analyses published in $2002^{23}$ and $2006^{24}$ pooled the data from publications on breast cancer survival that adjusted for socioeconomic status in African-American compared with White-American patients, with both demonstrating that African-American identity remained a statistically significant risk factor for adverse outcomes. The latter report featured data represented by $>14,000$ African-American and 76,000 White-American patients, revealing a statistically significant mortality hazard ratio of 1.27 (95\% CI, $1.18-1.38){ }^{24}$

Another approach to evaluating breast cancer disparities related to racial/ethnic identity involves the evaluation of data from clinical trials. The bedrock principle of the cancer clinical trials mechanism is that highest-level evidence regarding optimal oncology care is provided through monitoring outcomes in patients receiving tightly regulated and standardized treatment regimens. Albain et $\mathrm{al}^{25}$ attempted to address the question of whether equal treatment in the context of clinical trial participation resulted in equal outcomes (regardless of racial/ethnic identity) by evaluating data from prospective, randomized trials from the Southwest Oncology Group. This robust pooled analysis of data from nearly 20,000 cancer patients (approximately 12\% African Americans) treated in 35 trials between 1974 and 2001 found that racial/ethnic identity did not affect outcomes in the majority of malignancies, but results differed in the hormonally driven, sex-specific cancers. Outcome disparities related to African-American identity were observed in breast, prostate, and ovarian cancers, but not in lung or colon cancer, or in lymphoma, leukemia, or myeloma. Ten-year overall survival in premenopausal African-American women with early-stage breast cancer was $68 \%$ compared 
with $77 \%$ in comparable patients with other racial/ethnic identities, and $52 \%$ versus $62 \%$, respectively, in those with early-stage, postmenopausal breast cancer. ${ }^{25}$

The Women's Health Initiative is a massive prospective study of postmenopausal women's health that includes data on the incidence of breast cancer among $>150,000$ participants. After a median follow-up of 6.3 years, nearly 4000 breast cancers were diagnosed, and among this entire cohort of carefully screened women, the African-American participants were nearly five times as likely as the White Americans to develop high-grade, receptor-negative breast cancers, and the group had a significantly higher mortality hazard ratio of 1.79 (95\% CI, 1.05 to 3.05$){ }^{26}$ The expression of the HER2/Neu biomarker was not included in this analysis.

The approximately twofold increased risk for TNBC in African-American women has been confirmed by populationbased incidence rates regionally ${ }^{27}$ as well as nationally, ${ }^{3}$ and across all age intervals. Compared with non-TNBC, triplenegative disease has been confirmed to be an adverse prognostic feature in African-American patients. ${ }^{28}$ It is also noteworthy that data from the Surveillance, Epidemiology, and End Results Program linked to the American Community Survey failed to demonstrate an association between TNBC and socioeconomic status. ${ }^{29}$

International patterns of breast cancer biomarker expression have prompted additional hypothesis-generating observations regarding a possible hereditary link between African ancestry and the triple-negative phenotype. Population-based data on breast cancer burden in Africa are sparse, but several studies have revealed notably higher frequencies of estrogen receptor-negative disease and TNBC among African patients. ${ }^{6,30,31}$ The highest prevalence rates are observed in western, sub-Saharan Africa, where triple-negative disease has accounted for $27 \%$ to $61 \%$ of cases. ${ }^{32-37}$ In contrast, the frequency of TNBC is $<20 \%$ in many studies in patients from northern and eastern Africa. ${ }^{5,38-41}$ The colonial-era transAtlantic slave trade resulted in the forced migration of Africans from the continent's gold coast to the Americas, resulting in shared ancestry between African Americans and western, sub-Saharan Africans ${ }^{42}$ and potentially explaining similarities in breast cancer patterns in these two population subsets.

\section{Biology and Genetics of TNBC}

TNBCs have morphologic growth patterns illustrating heterogeneity and highlighting distinctive biological features, clinical presentations, responses to therapy, and outcomes. There are several morphologic variants, with the high histologic grade invasive ductal carcinoma being the most common, associated with high mitotic rates, central necrotic or fibrotic zones, pushing borders, and conspicuous lymphocytic infiltrate. Other morphologies that are typically triple negative include medullary, secretory, and apocrine carcinomas - all of which have relatively more favorable biologic behaviors - and metaplastic carcinomas, which tend to be biologically more aggressive. This heterogeneous morphologic spectrum of subtypes is further supported and defined by diverse genetic pathways. Lehmann et $\mathrm{al}^{43}$ were among the early investigators identifying these triplenegative subtypes, and their efforts were based on analyses of gene-expression profiles from 21 publicly available data sets that included 587 TNBC cases. They identified six different subtypes-two basal-like subtypes, an immunomodulatory subtype, a mesenchymal subtype, a mesenchymal stem-like subtype, and a luminal androgen receptor subtype. Similarly, Burstein et $\mathrm{al}^{44}$ identified four TNBC subtypes based on the gene-expression profiles of 198 cases from the Baylor College of Medicine (Houston, TX): i) a luminal androgen receptor subtype; ii) a mesenchymal subtype; iii) a basal-like immune-suppressed subtype; and iv) a basal-like immune-activated subtype. These different patterns have been shown to be associated with prognostic as well as predictive therapeutic value; the luminal androgen receptor subtype tends to respond poorly to neoadjuvant chemotherapy $^{45,46}$ and may be amenable to endocrine manipulation through anti-androgen therapy. Unfortunately, however, neither of these data sets included meaningful samples of triple-negative tumors from women of African ancestry.

A few studies have provided limited but important findings with regard to gene-expression profiles of African-American breast cancer patients. Lindner et $\mathrm{al}^{47}$ evaluated 136 tumors from the Yale TNBC cohort (including 50 African-American patients) and found basal-like subtypes to be more common among the African-American cases; they also reported differential activation of insulin-like growth factor 1 and a signature of breast cancer 1 susceptibility protein (BRCA1) deficiency in the African-American samples. Keenan et $\mathrm{al}^{48}$ utilized The Cancer Genome Atlas to investigate exome sequencing in 663 White-American compared with 105 African-American cases, and gene-expression data in 711 White-American compared with 159 African-American cases. The African Americans had more basal tumors overall, and within the triple-negative category they were also more likely to have the basal-like and mesenchymal triple-negative subtypes. Recently, Ademuyiwa et al ${ }^{49}$ evaluated 1104 Cancer Genome Atlas breast cancers (including 178 triple-negative tumors) and similarly found the triple-negative phenotype as well as the basal subtype to be more frequent in African Americans compared with White Americans (33.3\% vs 14.9\% and $34.8 \%$ vs $16.1 \%$, respectively). TNBC-specific subtyping was not reported, but these investigators did not identify significant differences in gene-expression patterns between African-American and White-American TNBC cases in the genes that were selected for analysis. Huo et $\mathrm{al}^{50}$ also reported on the increased frequency of basal subtype tumors among African-American compared with White-American cases from The Cancer Genome Atlas, and their The Cancer Genome Atlas interrogation furthermore suggested that $>40 \%$ of differences in frequencies of breast cancer subtypes 
Table 1 Studies Reporting on the Landscape of Somatic Mutations in Breast Cancers of African-American and White-American Patients

\begin{tabular}{|c|c|c|}
\hline Study & Cases studied & Selected findings \\
\hline Martin et $\mathrm{al}^{51}$ & $\begin{array}{l}\text { Baltimore, MD } \\
18 \text { AA ( } 72 \% \text { ER-negative) } \\
17 \text { WA ( } 29 \% \text { ER-negative) }\end{array}$ & $\begin{array}{l}\text { - Prominent interferon signal in tumors of AA patients } \\
\text { - Phosphoserine phosphatase-like expressed more highly in tumor } \\
\text { epithelium and stroma of AA patients } \\
\text { - Thymopoietin expressed more highly in stroma of AA patients } \\
\text { - Chemokine ligands } 10 \text { and } 11 \text { expressed more strongly in tumor stroma of } \\
\text { AA patients }\end{array}$ \\
\hline
\end{tabular}

Grunda et $\mathrm{al}^{53} \quad$ Birmingham, $\mathrm{AL}$

11 AA (45\% ER-negative)

11 WA (9\% ER-negative)

Stewart et $\mathrm{al}^{54} \quad$ The Cancer Genome Atlas 53 AA (19\% TNBC)

574 WA (12\% TNBC)

Lindner et $\mathrm{al}^{47}$

Yale TNBC Cohort

$50 \mathrm{AA}$

69 WA

Kroenke et $\mathrm{al}^{55}$

Pathways and Life after Cancer Epidemiology Cohorts

128 AA (30\% TNBC)

1176 WA (11\% TNBC)

Sweeney et $\mathrm{al}^{56} \quad$ Pathways and Life after Cancer Epidemiology Cohorts

$115 \mathrm{AA}^{*}$

$913 W^{*}$ *

$12 \%$ of entire cohort with TNBC;

frequencies not reported by race/ethnicity

Keenan et $\mathrm{al}^{48} \quad$ The Cancer Genome Atlas

159 AA (17\% TNBC)

711 WA $(8 \%$ TNBC)

Ademuyiwa et $\mathrm{al}^{49}$ The Cancer Genome Atlas

183 AA $(33 \%$ TNBC)

764 WA $(15 \%$ TNBC)

Huo et $\mathrm{al}^{50} \quad$ The Cancer Genome Atlas

$154 \mathrm{AA}$

776 WA
- AA patients more likely to have aberrant $\mathrm{G} 1 / \mathrm{S}$ cell-cycle regulatory genes

- AA patients more likely to have decreased expression of cell adhesion genes

- AA patients more likely to have low or no expression of ESR1, PR, c-ErbB2 and estrogen pathway genes

- Increase in number of differentially expressed genes between AA and WA patients with each stage of tumor progression

- Resistin (a gene that is linked to obesity, insulin resistance, and breast cancer) was expressed more than four times higher in AA cases, but was lowest in AA TNBC tumors

- Increased expression of p53 and BRCA1 subnetwork components in AA tumors

- Major transcriptional signature of proliferation found to be up-regulated in AA cases

- Differential activation of insulin-like growth factor 1 and a signature of BRCA1 deficiency in AA cases

- TNBC subtyping revealed AA cases more likely to have basal subtype compared with WA cases

- PAM50 subtyping revealed increased frequency of basal subtype among AA compared with WA cases ( $41 \%$ vs $17 \%$ )

- PAM50 subtyping revealed increased frequency of basal subtype among AA cases; odds ratio for having basal vs luminal A subtype (with WA as referent group) 4.38 (95\% CI, 2.29-8.39)

- PAM50 subtyping revealed increased frequency of basal subtype in AA cases (39\% vs $19 \%$ ) and fewer luminal A tumors (17\% vs $35 \%$ )

- TNBC subtyping revealed increased frequency of basal-like 1 and mesenchymal stem-like tumors in AA vs WA cases; no LAR tumors in the AA cases

- PAM50 subtyping revealed increased frequency of basal subtype in AA cases (35\% vs $16 \%$ )

- Median counts of somatic tumor mutations higher in AA vs WA cases overall

- No significant differences in median mutation counts for AA TNBC compared with WA TNBC cases

- PAM50 subtyping revealed increased frequency of basal subtype in AA cases $(36 \%$ vs $15 \% ; P<0.0001)$

- AA cases with more TP53 and fewer PIK3CA mutations compared with WA [52\% vs $31 \%\left(P=2.5 \times 10^{-5}\right)$ and $24 \%$ vs $36 \% ;(P=0.012)$, respectively]; African ancestry vs European ancestry cases defined by Ancestry Informative Markers

*Estimated from percentage distributions provided.

AA, African American; BRCA, breast cancer susceptibility protein; c-ErbB2, receptor tyrosine-protein kinase erbB-2; ER, estrogen receptor; ESRI, estrogen receptor 1; LAR, leukocyte common antigen related; PAM50, Prosigna Breast Cancer Prognostic Gene Signature Assay (NanoString Technologies, Inc, Seattle, WA); PR, progesterone receptor; TNBC, triple-negative breast cancer; WA, white American. 
may be explained by genetic variants. Table 1 summarizes some key findings from gene-expression studies reported on cases of breast cancer in African-American compared with White-American patients. ${ }^{51-56}$

The disproportionately high rates of triple-negative and basal breast cancer subtypes among African-American patients undoubtedly contributes to outcome disparities. Available data thus far are inconsistent in determining whether African-American identity and/or African ancestry remains a significant risk factor for adverse breast cancer outcomes within the subsets of patients documented as having these biologically aggressive (and often overlapping) patterns of disease. ${ }^{5-60}$ TNBC subtyping in patients with African ancestry may further inform the discussion of whether disparities in breast cancer outcomes persist after accounting for conventional breast cancer phenotype. Furthermore, additional studies of germline genetics correlating African ancestry with breast cancer risk are also imperative in answering the underlying question of why these virulent patterns of breast cancer are more common in this population subset.

\section{Breast Cancer Stem Cells and TNBC}

The hallmark feature of stem cells is the ability to self-renew and to produce diverse progeny. Mammary stem cells (MaSCs) were identified several decades ago and are distinguished by the capacity to regenerate a fully developed mammary gland after individual implantation of these multipotent cells into specially prepared recipient mice. ${ }^{61,62}$ Theoretically, any cell produced along the pathway from the parent MaSC through a multipotent progenitor, to a committed progenitor, and ultimately to a differentiated mammary gland cell can experience some aberrant oncogenic activity and transform into a mammary cancer stem cell, hereafter called a BCSC. Differentiated epithelial cells are expected to interact with their microenvironment in a well-regulated fashion, but they will occasionally be triggered to assume mesenchymal properties featuring the capacity to migrate and avoid apoptosis. This process is called epithelial-to-mesenchymal transition, and plasticity refers to the ability of cells to transition between these patterns. The stem cell theory therefore describes both normal mammary tissue and malignancies as featuring a hierarchical structure, with the noncancerous and cancerous stem cells both located at the apices of their respective organizations, but with the normal MaSCs producing differentiated progeny that include luminal (ductal and lobular-alveolar) as well as myoepithelial cells; in contrast, the BCSCs (alias breast cancer-initiating cells) produce neoplastic progeny that possess varying degrees of dedifferentiation and tumor-initiating traits. The MaSCs and BCSCs are the only components that have the abilities to both self-renew and regenerate the full spectrum of diverse tissues within the overall mammary gland or mammary cancer, respectively. A detailed discussion of these complex processes is beyond the scope of this article, but some of the key elements are depicted in Figure 1 and have been explored more comprehensively by others. ${ }^{63-69}$

As described in the previous paragraph, BCSCs represent the subpopulation of tumor cells that can self-renew and recapitulate the parent tumor (as demonstrated by xenotransplantation studies), whereas the cancer cells lacking the BCSC properties do not have this capacity. The latter nonBCSCs tend to comprise the bulk of the detected tumor and its metastases, whereas the minority-subpopulation BCSCs account for the metastatic virulence. Conventional (nontargeted) chemotherapy regimens typically focus on exterminating the hyperproliferative and abundant non-BCSC population. Efforts to identify MaSCs as well as BCSCs, to correlate breast cancer phenotypes with BCSC activity, and to develop therapies that disrupt the BCSC metastatic progression therefore represent exciting prospects in precisionmedicine research. ${ }^{63,70}$

Reliable, accurate strategies to identify and isolate BCSCs have been elusive. Flow cytometry and fluorescence-activated cell sorting to detect surface-marker signatures $\mathrm{CD} 44^{+} / \mathrm{CD} 24^{\text {low/- }}$ and epithelial cell adhesion

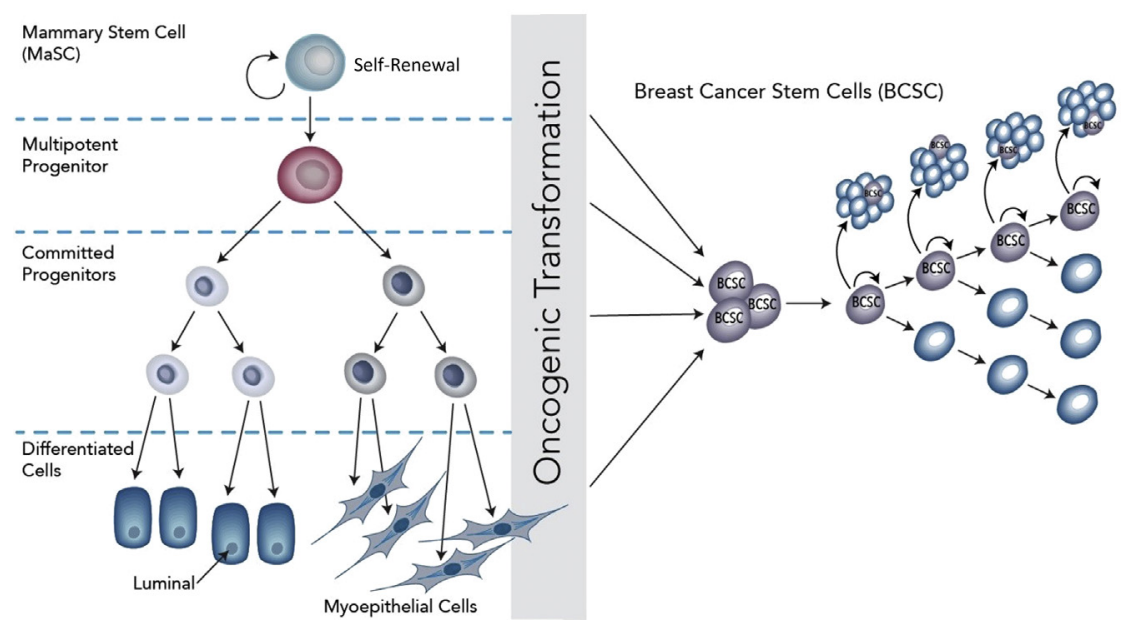

Figure 1 Breast cancer arises from cells harboring dysregulated self-renewal capability resulting from tumorigenic mutations and/or epigenetic modifications. Mammary stem cells and breast cancer stem cells both have the dual abilities to self-renew and differentiate. In the breast cancer stem cells, the capacity for self-renewal enables tumor initiation and growth; the capacity for differentiation allows for generating the bulk tumor cells and tumor cell heterogeneity. Modified and adapted with permission from Lin et $\mathrm{al}^{63}$ and Reya et al. ${ }^{69}$ 
molecule/epithelial-specific antigen positivity have been among the most popular strategies. The Aldefluor assay (Stem Cell Technologies, Inc., Vancouver, BC, Canada) is also widely used to detect intracellular aldehyde dehydrogenase (ALDH) activity. Immunohistochemistry (IHC) analysis to detect these markers has also been utilized. These same proteins have been considered as putative markers of the MaSC in normal breast tissue. Although the prognostic value of these markers has not been definitively determined, findings from several studies have shown that tumors with higher proportions of cancerous stem cells indicated by any of these markers are associated with a worse prognosis. ${ }^{63,71-73}$

In malignant breast tissue, studies have indicated minimal overlap between the $\mathrm{CD} 44^{+} / \mathrm{CD} 24^{\text {low/- }}$ and ALDH populations (suggesting that they represent distinct and separate BCSCs) but tumors that are enriched with both BCSC types are especially virulent. The $\mathrm{CD} 44^{+} / \mathrm{CD} 24^{\text {low/-}}$ cells have been associated with an enhanced capacity for detaching from the primary tumor and metastasizing (supported by a dominant epithelial-to-mesenchymal transition gene-expression profile), whereas the ALDH BCSCs appear to feature a stronger predisposition for replicating and thereby possibly yielding more of the non-BCSC progeny that account for the bulk of the tumor (supported by their dominant mesenchymal-toepithelial transition gene-expression profile). ${ }^{63,68,74}$

It is unknown at present whether a direct link exists between specific BCSCs and individual breast cancer subtypes. The $\mathrm{CD} 44^{+} / \mathrm{CD} 24^{\text {low/ }}$ and the ALDH BCSCs have both been correlated with high-grade, basal-like, and HER2/Neu-overexpressing tumors. ${ }^{10,63,75-78}$ Another potentially therapeutically relevant theory is that HER2/Neu-related oncogenic activity in BCSCs may be independent of HER2/ $\mathrm{Neu}$ expression as identified by standard IHC analysis, thereby explaining why some patients with HER2/Neu-negative breast cancers derive an outcome advantage from targeted antiHER2/Neu therapy. ${ }^{79,80}$

\section{Breast Cancer Stem Cells and African Ancestry}

Triple-negative and basal subtype breast cancers are more common among African-American compared with WhiteAmerican women, and breast cancer mortality rates are higher among African Americans. Preliminary data suggest that basal breast cancers are enriched with populations of cells that feature BCSC markers, and this feature may account for the metastatic potential of aggressive breast cancer subtypes. Very little is known regarding BCSC patterns in women of African ancestry, as most stem cell research in humans has been based on specimens from White-American, European, and Asian patient populations.

Nakshatri et al ${ }^{13}$ evaluated the distribution of MaSC phenotypes (defined by cell surface markers assessed with flow cytometry) in African-American and White-American women that donated healthy breast tissue specimens to the Susan G.
Komen Tissue Bank (Indianapolis, IN). These investigators found significant elevations in $\mathrm{CD} 44^{+} / \mathrm{CD} 24^{-}$and endothelial protein $\mathrm{C}$ receptor-positive/epithelial cell adhesion molecule-negative multipotent stem cells in the tissues from African-American compared with White-American donors.

The candidate BCSC marker ALDH1 has been evaluated by a few different data sets of breast tumors in women of African ancestry, with most of these studies using IHC analysis methodology. Although there is no standardized cut point for assigning ALDH1 positivity, most studies in White-American and European breast cancer patients report less than one-third of cases to have ALDH1 overexpression. ${ }^{11,71}$ Nalwoga et al ${ }^{12}$ analyzed 192 breast cancers from the Makerere University College of Health Sciences (Kampala, Uganda) by IHC analysis applied to tissue microarrays and found ALDH1 expression in $48 \%$ of cases; ALDH1 expression was also associated with high-grade and triple-negative tumors. Schwartz et $\mathrm{al}^{11}$ reported overexpression of ALDH1 in $42 \%$ and $17 \%$ of the stromal and epithelial compartments, respectively, from 104 Ghanaian breast cancer cases. These investigators also found notably higher expression of ALDH1 in TNBCs as well as in benign breast tissue from Ghanaian patients. An updated and expanded but unpublished series from this group found ALDH1 expression to be increased among specimens from African-American and Ghanaian breast cancer patients (32\% and 36\%, respectively) compared with WhiteAmerican and Ethiopian patients $(23 \%$ and $17 \%$, respectively; $P=0.007$ ).

The concept of assessing cancer stem cells as a factor in outcome disparities related to racial/ethnic identity is gaining traction in other, non-breast disease sites. Recent studies by Farhana et $\mathrm{al}^{81}$ and Goyal et $\mathrm{al}^{82}$ have proposed that increased cancer stem cell activity may explain the increase in colorectal cancer prevalence as well as mortality among African Americans compared with White Americans. Broadening the research opportunities related to stem cells and diverse patient populations even further, Chang et $\mathrm{al}^{83}$ recently reported on the generation of xenofree human induced pluripotent stem cell lines from fibroblasts obtained from individuals representing WhiteAmerican, African-American, Hispanic/Latino, and Asian backgrounds.

\section{Conclusions}

Achieving the full potential of precision medicine in cancer by delivering truly personalized care requires that all elements of the oncology pathway be addressed. This complex picture includes germline genetic patterns as well as somatic/tumor genetics. The stem cell model in mammary tissue as well as in breast cancers suggests that it is equally important to identify and characterize the subpopulation of tumor cells that is involved in metastatic virulence. Racial/ethnic identity can be correlated with germline 
genetics/hereditary cancer susceptibility and tumor phenotype; it is therefore imperative that stem cell biology be explored in the context of patients of diverse racial and ethnic backgrounds. These issues are especially important in breast cancer, in which women of African ancestry are well known to experience higher mortality from breast cancer, and this disparity is at least partly explained by a disproportionate risk for triple-negative and basal breast cancer subtypes.

\section{Acknowledgments} We thank Jack Butler and Kelly Comerford (Henry Ford
Health System) for assistance with creating Figure 1.

\section{References}

1. Charafe-Jauffret E, Ginestier C, Iovino F, Wicinski J, Cervera N, Finetti P, Hur MH, Diebel ME, Monville F, Dutcher J, Brown M, Viens P, Xerri L, Bertucci F, Stassi G, Dontu G, Birnbaum D, Wicha MS: Breast cancer cell lines contain functional cancer stem cells with metastatic capacity and a distinct molecular signature. Cancer Res 2009, 69:1302-1313

2. Dontu G, Abdallah WM, Foley JM, Jackson KW, Clarke MF, Kawamura MJ, Wicha MS: In vitro propagation and transcriptional profiling of human mammary stem/progenitor cells. Genes Dev 2003, 17:1253-1270

3. Kohler BA, Sherman RL, Howlader N, Jemal A, Ryerson AB, Henry KA, Boscoe FP, Cronin KA, Lake A, Noone AM, Henley SJ, Eheman CR, Anderson RN, Penberthy L: Annual report to the nation on the status of cancer, 1975-2011, featuring incidence of breast cancer subtypes by race/ethnicity, poverty, and state. J Natl Cancer Inst 2015, 107:djv048

4. Newman LA, Reis-Filho JS, Morrow M, Carey LA, King TA: The 2014 Society of Surgical Oncology Susan G. Komen for the Cure Symposium: triple-negative breast cancer. Ann Surg Oncol 2015, 22:874-882

5. Jiagge E, Jibril AS, Chitale D, Bensenhaver JM, Awuah B, Hoenerhoff M, Adjei E, Bekele M, Abebe E, Nathanson SD, Gyan K, Salem B, Oppong J, Aitpillah F, Kyei I, Bonsu EO, Proctor E, Merajver SD, Wicha M, Stark A, Newman LA: Comparative analysis of breast cancer phenotypes in African American, White American, and West versus East African patients: correlation between African ancestry and triple-negative breast cancer. Ann Surg Oncol 2016, 23:3843-3849

6. Brewster AM, Chavez-MacGregor M, Brown P: Epidemiology, biology, and treatment of triple-negative breast cancer in women of African ancestry. Lancet Oncol 2014, 15:e625-e634

7. Yang F, Cao L, Sun Z, Jin J, Fang H, Zhang W, Guan X: Evaluation of breast cancer stem cells and intratumor stemness heterogeneity in triple-negative breast cancer as prognostic factors. Int J Biol Sci 2016, 12:1568-1577

8. Guler G, Balci S, Costinean S, Ussakli C, Irkkan C, Suren D, Sari E, Altundag K, Ozisik Y, Jones S, Bacher J, Shapiro C, Huebner K: Stem cell-related markers in primary breast cancers and associated metastatic lesions. Mod Pathol 2012, 25:949-955

9. Olsson E, Honeth G, Bendahl PO, Saal LH, Gruvberger-Saal S, Ringner M, Vallon-Christersson J, Jonsson G, Holm K, Lovgren K, Ferno M, Grabau D, Borg A, Hegardt C: CD44 isoforms are heterogeneously expressed in breast cancer and correlate with tumor subtypes and cancer stem cell markers. BMC Cancer 2011, 11:418

10. Honeth G, Bendahl PO, Ringner M, Saal LH, Gruvberger-Saal SK, Lovgren K, Grabau D, Ferno M, Borg A, Hegardt C: The CD44+/CD24- phenotype is enriched in basal-like breast tumors. Breast Cancer Res 2008, 10:R53
11. Schwartz T, Stark A, Pang J, Awuah B, Kleer CG, Quayson S, Kingman S, Aitpillah F, Abantanga F, Jiagge E, Oppong JK, OseiBonsu E, Martin I, Yan X, Toy K, Adjei E, Wicha M, Newman LA: Expression of aldehyde dehydrogenase 1 as a marker of mammary stem cells in benign and malignant breast lesions of Ghanaian women. Cancer 2013, 119:488-494

12. Nalwoga H, Arnes JB, Wabinga H, Akslen LA: Expression of aldehyde dehydrogenase 1 (ALDH1) is associated with basal-like markers and features of aggressive tumours in African breast cancer. Br J Cancer 2010, 102:369-375

13. Nakshatri H, Anjanappa M, Bhat-Nakshatri P: Ethnicity-dependent and -independent heterogeneity in healthy normal breast hierarchy impacts tumor characterization. Sci Rep 2015, 5:13526

14. Pang J, Toy KA, Griffith KA, Awuah B, Quayson S, Newman LA, Kleer CG: Invasive breast carcinomas in Ghana: high frequency of high grade, basal-like histology and high EZH2 expression. Breast Cancer Res Treat 2012, 135:59-66

15. Newman LA, Kaljee LM: Health disparities and triple-negative breast cancer in African American women: a review. JAMA Surg 2017, 152:485-493

16. DeSantis CE, Fedewa SA, Goding Sauer A, Kramer JL, Smith RA, Jemal A: Breast cancer statistics, 2015: convergence of incidence rates between black and white women. CA Cancer J Clin 2016, 66: $31-42$

17. Baquet CR, Mishra SI, Commiskey P, Ellison GL, DeShields M: Breast cancer epidemiology in blacks and whites: disparities in incidence, mortality, survival rates and histology. J Natl Med Assoc 2008, 100:480-488

18. Bigby J, Holmes MD: Disparities across the breast cancer continuum. Cancer Causes Control 2005, 16:35-44

19. Tannenbaum SL, Koru-Sengul T, Miao F, Byrne MM: Disparities in survival after female breast cancer diagnosis: a population-based study. Cancer Causes Control 2013, 24:1705-1715

20. Tian N, Goovaerts P, Zhan FB, Chow TE, Wilson JG: Identifying risk factors for disparities in breast cancer mortality among AfricanAmerican and Hispanic women. Womens Health Issues 2012, 22: e267-e276

21. Deshpande AD, Jeffe DB, Gnerlich J, Iqbal AZ, Thummalakunta A, Margenthaler JA: Racial disparities in breast cancer survival: an analysis by age and stage. J Surg Res 2009, 153:105-113

22. Newman LA: Parsing the etiology of breast cancer disparities. J Clin Oncol 2016, 34:1013-1014

23. Newman LA, Mason J, Cote D, Vin Y, Carolin K, Bouwman D, Colditz GA: African-American ethnicity, socioeconomic status, and breast cancer survival: a meta-analysis of 14 studies involving over 10,000 African-American and 40,000 White American patients with carcinoma of the breast. Cancer 2002, 94:2844-2854

24. Newman LA, Griffith KA, Jatoi I, Simon MS, Crowe JP, Colditz GA: Meta-analysis of survival in African American and white American patients with breast cancer: ethnicity compared with socioeconomic status. J Clin Oncol 2006, 24:1342-1349

25. Albain KS, Unger JM, Crowley JJ, Coltman CA Jr, Hershman DL: Racial disparities in cancer survival among randomized clinical trials patients of the Southwest Oncology Group. J Natl Cancer Inst 2009, 101:984-992

26. Chlebowski RT, Chen Z, Anderson GL, Rohan T, Aragaki A, Lane D, Dolan NC, Paskett ED, McTiernan A, Hubbell FA, AdamsCampbell LL, Prentice R: Ethnicity and breast cancer: factors influencing differences in incidence and outcome. J Natl Cancer Inst 2005, 97:439-448

27. Amirikia KC, Mills P, Bush J, Newman LA: Higher population-based incidence rates of triple-negative breast cancer among young AfricanAmerican women: implications for breast cancer screening recommendations. Cancer 2011, 117:2747-2753

28. Akinyemiju T, Moore JX, Altekruse SF: Breast cancer survival in African-American women by hormone receptor subtypes. Breast Cancer Res Treat 2015, 153:211-218 
29. Akinyemiju TF, Pisu M, Waterbor JW, Altekruse SF: Socioeconomic status and incidence of breast cancer by hormone receptor subtype. Springerplus 2015, 4:508

30. Newman LA: Disparities in breast cancer and African ancestry: a global perspective. Breast J 2015, 21:133-139

31. Jiagge E, Bensenhaver JM, Oppong JK, Awuah B, Newman LA: Global surgical oncology disease burden: addressing disparities via global surgery initiatives: the University of Michigan International Breast Cancer Registry. Ann Surg Oncol 2015, 22:734-740

32. Huo D, Ikpatt F, Khramtsov A, Dangou JM, Nanda R, Dignam J, Zhang B, Grushko T, Zhang C, Oluwasola O, Malaka D, Malami S, Odetunde A, Adeoye AO, Iyare F, Falusi A, Perou CM, Olopade OI: Population differences in breast cancer: survey in indigenous African women reveals over-representation of triple-negative breast cancer. J Clin Oncol 2009, 27:4515-4521

33. Ly M, Antoine M, Dembele AK, Levy P, Rodenas A, Toure BA, Badiaga Y, Dembele BK, Bagayogo DC, Diallo YL, Kone AA, Callard P, Bernaudin JF, Diallo DA: High incidence of triple-negative tumors in sub-Saharan Africa: a prospective study of breast cancer characteristics and risk factors in Malian women seen in a Bamako university hospital. Oncology 2012, 83:257-263

34. Der EM, Gyasi RK, Tettey Y, Edusei L, Bayor MT, Jiagge E, Gyakobo M, Merajver SD, Newman LA: Triple-negative breast cancer in Ghanaian women: the Korle Bu Teaching Hospital experience. Breast J 2015, 21:627-633

35. Ohene-Yeboah M, Adjei E: Breast cancer in Kumasi, Ghana. Ghana Med J 2012, 46:8-13

36. Nwafor CC, Keshinro SO: Pattern of hormone receptors and human epidermal growth factor receptor 2 status in sub-Saharan breast cancer cases: private practice experience. Niger J Clin Pract 2015, 18: $553-558$

37. Proctor E, Kidwell KM, Jiagge E, Bensenhaver J, Awuah B, Gyan K, Toy K, Oppong JK, Kyei I, Aitpillah F, Osei-Bonsu E, Adjei E, Ohene-Yeboah M, Brewer RN, Fondjo LA, Owusu-Afriyie O, Wicha M, Merajver S, Kleer C, Newman L: Characterizing breast cancer in a population with increased prevalence of triple-negative breast cancer: androgen receptor and ALDH1 expression in Ghanaian women. Ann Surg Oncol 2015, 22:3831-3835

38. Rais G, Raissouni S, Aitelhaj M, Rais F, Naciri S, Khoyaali S, Abahssain H, Bensouda Y, Khannoussi B, Mrabti H, Errihani H: Triple negative breast cancer in Moroccan women: clinicopathological and therapeutic study at the National Institute of Oncology. BMC Womens Health 2012, 12:35

39. Bennis S, Abbass F, Akasbi Y, Znati K, Joutei KA, El Mesbahi O, Amarti A: Prevalence of molecular subtypes and prognosis of invasive breast cancer in north-east of Morocco: retrospective study. BMC Res Notes 2012, 5:436

40. Salhia B, Tapia C, Ishak EA, Gaber S, Berghuis B, Hussain KH, DuQuette RA, Resau J, Carpten J: Molecular subtype analysis determines the association of advanced breast cancer in Egypt with favorable biology. BMC Womens Health 2011, 11:44

41. Aiad HA, Wahed MM, Asaad NY, El-Tahmody M, Elhosary E: Immunohistochemical expression of GPR30 in breast carcinoma of Egyptian patients: an association with immunohistochemical subtypes. APMIS 2014, 122:976-984

42. Campbell MC, Hirbo JB, Townsend JP, Tishkoff SA: The peopling of the African continent and the diaspora into the new world. Curr Opin Genet Dev 2014, 29:120-132

43. Lehmann BD, Bauer JA, Chen X, Sanders ME, Chakravarthy AB, Shyr Y, Pietenpol JA: Identification of human triple-negative breast cancer subtypes and preclinical models for selection of targeted therapies. J Clin Invest 2011, 121:2750-2767

44. Burstein MD, Tsimelzon A, Poage GM, Covington KR, Contreras A, Fuqua SA, Savage MI, Osborne CK, Hilsenbeck SG, Chang JC, Mills GB, Lau CC, Brown PH: Comprehensive genomic analysis identifies novel subtypes and targets of triple-negative breast cancer. Clin Cancer Res 2015, 21:1688-1698
45. Masuda H, Baggerly KA, Wang Y, Zhang Y, Gonzalez-Angulo AM, Meric-Bernstam F, Valero V, Lehmann BD, Pietenpol JA, Hortobagyi GN, Symmans WF, Ueno NT: Differential response to neoadjuvant chemotherapy among 7 triple-negative breast cancer molecular subtypes. Clin Cancer Res 2013, 19:5533-5540

46. Lehmann BD, Jovanovic B, Chen X, Estrada MV, Johnson KN, Shyr Y, Moses HL, Sanders ME, Pietenpol JA: Refinement of triplenegative breast cancer molecular subtypes: implications for neoadjuvant chemotherapy selection. PLoS One 2016, 11:e0157368

47. Lindner R, Sullivan C, Offor O, Lezon-Geyda K, Halligan K, Fischbach N, Shah M, Bossuyt V, Schulz V, Tuck DP, Harris LN: Molecular phenotypes in triple negative breast cancer from African American patients suggest targets for therapy. PLoS One 2013, 8: e71915

48. Keenan T, Moy B, Mroz EA, Ross K, Niemierko A, Rocco JW, Isakoff S, Ellisen LW, Bardia A: Comparison of the genomic landscape between primary breast cancer in African American versus white women and the association of racial differences with tumor recurrence. J Clin Oncol 2015, 33:3621-3627

49. Ademuyiwa FO, Tao Y, Luo J, Weilbaecher K, Ma CX: Differences in the mutational landscape of triple-negative breast cancer in African Americans and Caucasians. Breast Cancer Res Treat 2017, 161: 491-499

50. Huo D, Hu H, Rhie SK, Gamazon ER, Cherniack AD, Liu J, Yoshimatsu TF, Pitt JJ, Hoadley KA, Troester M, Ru Y, Lichtenberg T, Sturtz LA, Shelley CS, Benz CC, Mills GB, Laird PW, Shriver CD, Perou CM, Olopade OI: Comparison of breast cancer molecular features and survival by African and European ancestry in the cancer genome atlas. JAMA Oncol 2017, 3: $1654-1662$

51. Martin DN, Boersma BJ, Yi M, Reimers M, Howe TM, Yfantis HG Tsai YC, Williams EH, Lee DH, Stephens RM, Weissman AM, Ambs S: Differences in the tumor microenvironment between African-American and European-American breast cancer patients. PLoS One 2009, 4:e4531

52. Field LA, Love B, Deyarmin B, Hooke JA, Shriver CD, Ellsworth RE: Identification of differentially expressed genes in breast tumors from African American compared with Caucasian women. Cancer 2012, 118:1334-1344

53. Grunda JM, Steg AD, He Q, Steciuk MR, Byan-Parker S, Johnson MR, Grizzle WE: Differential expression of breast cancerassociated genes between stage- and age-matched tumor specimens from African- and Caucasian-American Women diagnosed with breast cancer. BMC Res Notes 2012, 5:248

54. Stewart PA, Luks J, Roycik MD, Sang QX, Zhang J: Differentially expressed transcripts and dysregulated signaling pathways and networks in African American breast cancer. PLoS One 2013, 8:e82460

55. Kroenke CH, Sweeney C, Kwan ML, Quesenberry CP, Weltzien EK, Habel LA, Castillo A, Bernard PS, Factor RE, Kushi LH, Caan BJ: Race and breast cancer survival by intrinsic subtype based on PAM50 gene expression. Breast Cancer Res Treat 2014, 144:689-699

56. Sweeney C, Bernard PS, Factor RE, Kwan ML, Habel LA, Quesenberry CP Jr, Shakespear K, Weltzien EK, Stijleman IJ, Davis CA, Ebbert MT, Castillo A, Kushi LH, Caan BJ: Intrinsic subtypes from PAM50 gene expression assay in a population-based breast cancer cohort: differences by age, race, and tumor characteristics. Cancer Epidemiol Biomarkers Prev 2014, 23:714-724

57. Sachdev JC, Ahmed S, Mirza MM, Farooq A, Kronish L, Jahanzeb M: Does race affect outcomes in triple negative breast cancer? Breast Cancer 2010, 4:23-33

58. Dawood S, Broglio K, Kau SW, Green MC, Giordano SH, MericBernstam F, Buchholz TA, Albarracin C, Yang WT, Hennessy BT, Hortobagyi GN, Gonzalez-Angulo AM: Triple receptor-negative breast cancer: the effect of race on response to primary systemic treatment and survival outcomes. J Clin Oncol 2009, 27:220-226

59. O'Brien KM, Cole SR, Tse CK, Perou CM, Carey LA, Foulkes WD, Dressler LG, Geradts J, Millikan RC: Intrinsic breast tumor subtypes, 
race, and long-term survival in the Carolina Breast Cancer Study. Clin Cancer Res 2010, 16:6100-6110

60. Lund MJ, Trivers KF, Porter PL, Coates RJ, Leyland-Jones B, Brawley OW, Flagg EW, O’Regan RM, Gabram SG, Eley JW: Race and triple negative threats to breast cancer survival: a populationbased study in Atlanta, GA. Breast Cancer Res Treat 2009, 113: $357-370$

61. Kordon EC, Smith GH: An entire functional mammary gland may comprise the progeny from a single cell. Development 1998, 125: $1921-1930$

62. Hoshino K, Gardner WU: Transplantability and life span of mammary gland during serial transplantation in mice. Nature 1967, 213:193-194

63. Lin CY, Barry-Holson KQ, Allison KH: Breast cancer stem cells: are we ready to go from bench to bedside? Histopathology 2016, 68: 119-137

64. Kalluri R, Weinberg RA: The basics of epithelial-mesenchymal transition. J Clin Invest 2009, 119:1420-1428

65. Yang X, Wang H, Jiao B: Mammary gland stem cells and their application in breast cancer. Oncotarget 2017, 8:10675-10691

66. Weigand A, Boos AM, Tasbihi K, Beier JP, Dalton PD, Schrauder M, Horch RE, Beckmann MW, Strissel PL, Strick R: Selective isolation and characterization of primary cells from normal breast and tumors reveal plasticity of adipose derived stem cells. Breast Cancer Res 2016, 18:32

67. Wicha MS: Identification of murine mammary stem cells: implications for studies of mammary development and carcinogenesis. Breast Cancer Res 2006, 8:109

68. Luo M, Clouthier SG, Deol Y, Liu S, Nagrath S, Azizi E, Wicha MS: Breast cancer stem cells: current advances and clinical implications. Methods Mol Biol 2015, 1293:1-49

69. Reya T, Morrison SJ, Clarke MF, Weissman IL: Stem cells, cancer, and cancer stem cells. Nature 2001, 414:105-111

70. Liu S, Wicha MS: Targeting breast cancer stem cells. J Clin Oncol 2010, 28:4006-4012

71. Ginestier C, Hur MH, Charafe-Jauffret E, Monville F, Dutcher J, Brown M, Jacquemier J, Viens P, Kleer CG, Liu S, Schott A, Hayes D, Birnbaum D, Wicha MS, Dontu G: ALDH1 is a marker of normal and malignant human mammary stem cells and a predictor of poor clinical outcome. Cell Stem Cell 2007, 1:555-567

72. Liu Y, Lv DL, Duan JJ, Xu SL, Zhang JF, Yang XJ, Zhang X, Cui YH, Bian XW, Yu SC: ALDH1A1 expression correlates with clinicopathologic features and poor prognosis of breast cancer patients: a systematic review and meta-analysis. BMC Cancer 2014, 14:444
73. Amoury M, Kolberg K, Pham AT, Hristodorov D, Mladenov R, Di Fiore S, Helfrich W, Kiessling F, Fischer R, Pardo A, Thepen T, Hussain AF, Nachreiner T, Barth S: Granzyme B-based cytolytic fusion protein targeting EpCAM specifically kills triple negative breast cancer cells in vitro and inhibits tumor growth in a subcutaneous mouse tumor model. Cancer Lett 2016, 372:201-209

74. Luo M, Brooks M, Wicha MS: Epithelial-mesenchymal plasticity of breast cancer stem cells: implications for metastasis and therapeutic resistance. Curr Pharm Des 2015, 21:1301-1310

75. Ricardo S, Vieira AF, Gerhard R, Leitao D, Pinto R, CameselleTeijeiro JF, Milanezi F, Schmitt F, Paredes J: Breast cancer stem cell markers CD44, CD24 and ALDH1: expression distribution within intrinsic molecular subtype. J Clin Pathol 2011, 64:937-946

76. Sheridan C, Kishimoto H, Fuchs RK, Mehrotra S, Bhat-Nakshatri P, Turner CH, Goulet R Jr, Badve S, Nakshatri H: CD44+/CD24- breast cancer cells exhibit enhanced invasive properties: an early step necessary for metastasis. Breast Cancer Res 2006, 8:R59

77. Korkaya H, Paulson A, Iovino F, Wicha MS: HER2 regulates the mammary stem/progenitor cell population driving tumorigenesis and invasion. Oncogene 2008, 27:6120-6130

78. Park SY, Lee HE, Li H, Shipitsin M, Gelman R, Polyak K: Heterogeneity for stem cell-related markers according to tumor subtype and histologic stage in breast cancer. Clin Cancer Res 2010, 16:876-887

79. Korkaya H, Wicha MS: HER2 and breast cancer stem cells: more than meets the eye. Cancer Res 2013, 73:3489-3493

80. Ithimakin S, Day KC, Malik F, Zen Q, Dawsey SJ, BersanoBegey TF, Quraishi AA, Ignatoski KW, Daignault S, Davis A, Hall CL, Palanisamy N, Heath AN, Tawakkol N, Luther TK, Clouthier SG, Chadwick WA, Day ML, Kleer CG, Thomas DG, Hayes DF, Korkaya H, Wicha MS: HER2 drives luminal breast cancer stem cells in the absence of HER2 amplification: implications for efficacy of adjuvant trastuzumab. Cancer Res 2013, 73: $1635-1646$

81. Farhana L, Antaki F, Anees MR, Nangia-Makker P, Judd S, Hadden T, Levi E, Murshed F, Yu Y, Van Buren E, Ahmed K, Dyson G, Majumder AP: Role of cancer stem cells in racial disparity in colorectal cancer. Cancer Med 2015, 5:1268-1278

82. Goyal S, Nangia-Makker P, Farhana L, Yu Y, Majumdar AP: Racial disparity in colorectal cancer: gut microbiome and cancer stem cells. World J Stem Cells 2016, 8:279-287

83. Chang EA, Tomov ML, Suhr ST, Luo J, Olmsted ZT, Paluh JL, Cibelli J: Derivation of ethnically diverse human induced pluripotent stem cell lines. Sci Rep 2015, 5:15234 